\title{
PERANCANGAN DAYA GERAK PERAHU RAWA BERBASIS PROPULSI UDARA GUNA MENINGKATKAN KINERJA WAHANA PATROLI TNI AL
}

\section{SWAMP BOAT AIR PROPULSION BASED POWER DESIGN TO IMPROVE VEHICLE PERFORMANCE OF TNI AL}

\author{
A. Paripurna ${ }^{a}$, Samudroa, Suwahyua, R. Kharis ${ }^{a}$, H. Suyanto ${ }^{b}$ \\ a Pusat Teknologi Industri Pertahanan dan Keamanan \\ Deputi Teknologi Industri Rancang Bangun dan Rekayasa - BPPT \\ Gedung Hankam No. 256 Kawasan PUSPIPTEK - Serpong, Tangerang Selatan - 15314 \\ Telp. 021-75791262 (ext. 322) \\ e-mail : suwahyu@bppt.go.id \\ b Subdis Litbang Wahana, Dinas Penelitian dan Pengembangan TNI AL \\ Jl. Fatmawati No. 1, Pondok Labu, Jakarta Selatan \\ Telp. 021-7695041, Fax. 021-7695042
}

\begin{abstract}
Abstrak
Perahu Rawa (swamp boat) sebagai wahana taktis patroli militer TNI-AL dapat digunakan di rawa-rawa, perairan dangkal maupun sungai pedalaman. Perahu dirancang berbahan aluminium alloy dengan struktur lambung dasar rata (bottom flat) dilengkapi sistem propulsi berbalingbaling udara sehingga mampu melaju dan olah gerak dengan kecepatan tinggi. Sebagai wahana operasi patroli militer, kinerja perahu rawa perlu ditingkatkan melalui perancangan daya gerak sistem propulsi berbasis perhitungan baling-baling udara dalam kondisi hambatan air pada rancang bangun perahu rawa. Dalam studi ini dihasilkan rancangan secara perhitungan numerik propulsi di air perahu rawa berukuran panjang 5,8 $\mathrm{m}$ dengan bobot 2 Ton, berkecepatan hingga 50 knot, dengan hambatan air $6198,34 \mathrm{~N}$ yang membutuhkan tenaga dorong 267,5 HP. Dari evaluasi perbandingan antara perhitungan daya dorong berbasis perhitungan propulsi memakai baling-baling udara (engine propeller thrust) pada efisiensi $80 \%$ dan berbasis perhitungan propulsi di air, maka untuk mencapai kecepatan 50 knot hanya membutuhkan tenaga dorong (thrust) $8921,92 \mathrm{~N}$ setara daya dorong 238,1 HP. Oleh karena itu, untuk mengoptimalkan daya dorong sistem propulsi sebagai penggerak perahu pada kecepatan operasi 20 knot yang disyaratkan pada opsrec-spectec, digunakan alternatif mesin diesel dengan tenaga $275 \mathrm{HP} / 2500-3000 \mathrm{RPM}$ dilengkapi baling-baling udara berbahan komposit diameter 78". Hasil pengujian pelayaran perahu rawa di perairan terbatas menunjukkan hasil peningkatan kinerja kecepatan operasi $50 \%$, dicapai pada pada putaran baling-baling 2362,5 RPM dengan prestasi kecepatan operasi perahu rawa mencapai 30 knot.
\end{abstract}

Kata kunci : Perahu rawa, Hambatan air, Daya dorong, Peningkatan kecepatan operasi 


\begin{abstract}
Swamp boat as a vehicle of tactical military patrol of the Indonesian Navy can be used in the swamps, shallow waters or inland waterway. The design of Aluminum-alloy boat with a bottom flat hull structure is equipped with air propulsion and capable to navigate and maneuver with high speed. As a military patrol boat, the performance of swamp boat needs to be improved by the way of arrangement for propulsion power systembased air propulsion calculation on water resistance condition in engineering boat design. This study has produced a swamp boat design based numerical calculation of water propulsion, having particular of length about $5.8 \mathrm{~m}$, weight of 2 Tons, speed of 50 knots, with water resistance of $6198.34 \mathrm{~N}$ that requires a thrust power of $267.5 \mathrm{HP}$. From the evaluation of thrust power calculation based-air propulsion using air propeller at the propeller efficiency of $80 \%$ and based-water propulsion, in order to obtain the speed of 50 knots and water resistance of $6198.34 \mathrm{~N}$, the swamp boat has required the thrust power of $8921.92 \mathrm{~N}$ or equal to the thrust power of 238,1 HP. Hence, in order to optimize the thrust power of the propulsion system as a power engine of the swamp boat the required speed of higher than 20 knots, it is required to use a diesel engine of 275 HP/2500-3000 RPM and equipped with composite air propeller of 78" diameter. In limited water the sailing test results of swamp boat has shown that there has been an improvement of speed performance of about $50 \%$ at propeller revolution of 2362.5 RPM with the achievement speed of swamp boat up to 30 knots.
\end{abstract}

Key words : Swamp boat, Water resistance, Thrust power, Increasing Speed performance

Diterima (received ) : 27 September 2018 , Direvisi (revised ) : 01 Maret 2019

Disetujui (accepted) : 28 Maret 2019

\section{PENDAHULUAN}

Tugas pokok TNI AL tidak terbatas pada tugas tempur dalam mempertahankan wilayah yuridiksi perairan Indonesia, namun ikut juga melaksanakan tugas lain di bidang sosial kemasyarakatan, antara lain dalam pelaksanaan tugas patroli keamanan, bantuan tanggap darurat, kegiatan search and rescue (SAR). Terkait dengan beragam dan beratnya kondisi medan penugasan terutama patroli pengamanan di perairan laut pulau terluar, di perbatasan antar negara maupun sungai dan rawa-rawa di pedalaman, maka target utama dalam tugas pengamanan wilayah perairan adalah penguasaan penuh medan tugas operasi oleh setiap komponen pelaksana tugas dalam hal ini adalah satuan regu patroli $\mathrm{TNI} \mathrm{AL}^{1}{ }^{1}$. Dengan pertimbangan aspek tersebut, maka perlu dilakukan dukungan rancang bangun sarana patroli perairan dangkal, rawa-rawa yang memadai. Salah satu sarana yang tepat adalah Perahu Rawa (Swamp-Boat) yang juga banyak dikenal umum sebagai wahana transportasi air berbaling-baling udara (Air-boat), sebagaimana ditampilkan pada Gambar 1. Perahu rawa dengan bahan dasar aluminium alloy, bentuk lambung berdasar datar (flat bottom) dilengkapi sistem propulsi pendorong berbaling-baling udara dan sumber tenaga penggerak utama mesin diesel maupun mesin bensin berputaran tinggi. Sistem propulsi udara memang sengaja digunakan dikarenakan medan operasi perairan yang dangkal dan banyak tumbuhan air di sekitarnya, sehingga perahu konvensional dengan baling-baling terendam air tidak bisa digunakan. Dalam kajian ini perahu rawa dirancang untuk memenuhi kebutuhan tugas regu patroli militer sesuai dengan Technical Specification (Tecspec) TNI AL ${ }^{2)}$. Perahu rawa tipe militer dirancang dapat mengangkut satu regu patroli Marinir TNI AL (6 personel) untuk kebutuhan 5 jam operasi berlayar dengan kecepatan dinas 20 knot. Sebagai sarana patroli di air, perahu rawa juga dilengkapi persenjataan kaliber 12,7 $\mathrm{mm}$ terpasang di haluan dan perlengkapan patroli dan munisi untuk 6 personel serta logistik dan bahan bakar yang cukup untuk operasi di perairan pedalaman. Untuk dapat mendukung kebutuhan operasi patroli militer, maka perahu rawa harus memenuhi kriteria mudah dimobilisasikan, mudah dalam pengoperasian maupun perawatan serta 
ketersediaan suku cadang dan bahan bakar. Untuk kebutuhan tersebut, maka tenaga utama penggerak digunakan mesin diesel yang dapat berbahan bakar biodiesel serta lambung kapal dapat dengan mudah dibangun dan diperbaiki di bengkel galangan setempat. Khusus terkait dengan rancangan sistem propulsi perahu, maka pada kajian disini dilakukan perancangan daya gerak sistem propulsi udara berdasarkan pendekatan perhitungan propulsi di air untuk diacu dalam perhitungan propulsi udara serta hasilnya dilakukan analisis kinerja kecepatan dengan melakukan perbandingan antara data pengujian (seatrial) perahu rawa di perairan dalam kondisi muatan penuh dengan pemenuhan persyaratan sesuai spesifikasi teknik perahu dari TNI AL.

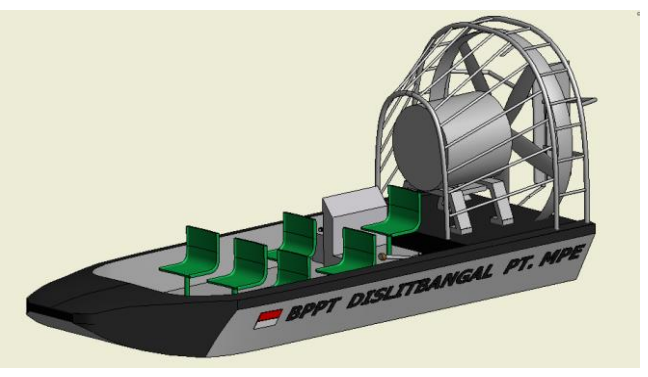

Gambar 1.

Rancangan awal 3D Perahu Rawa

\section{BAHAN DAN METODE}

Tabel 1.

Ukuran Utama Rancangan Perahu Rawa

\begin{tabular}{clc}
\hline No & Item Ukuran Utama & Ukuran \\
\hline $\mathbf{1}$ & Platform length (Lbp) & $5,80 \mathrm{~m}$ \\
$\mathbf{2}$ & Length over all (Loa) & $6,00 \mathrm{~m}$ \\
$\mathbf{3}$ & Breadth over all (Boa) & $2,40 \mathrm{~m}$ \\
$\mathbf{4}$ & Height & $0,50 \mathrm{~m}$ \\
$\mathbf{5}$ & Max. Draft & $0,25 \mathrm{~m}$ \\
$\mathbf{6}$ & Speed & $20 \mathrm{knot}$ \\
& Displacement & $\pm 2,0 \mathrm{ton}$ \\
\hline
\end{tabular}

Sebagai bahan utama pada kajian ini digunakan rancangan dasar prototip perahu rawa (Swamp Boat) untuk patroli melalui wacana perahu pembanding ${ }^{3)}$. Adapun ukuran utama rancangan perahu rawa ditampilkan pada Tabel 1. Sedangkan pada Tabel 2 ditampilkan konfigurasi pembanding berat perahu rawa LWT dan Tabel 3 ditampilkan komposisi beban muatan (Pay load) perahu rawa DWT.
Tabel 2.

Data Pembanding Berat (LWT)

\begin{tabular}{clc}
\hline No & \multicolumn{1}{c}{ Jenis Beban } & Berat $\mathbf{( K g )}$ \\
\hline $\mathbf{1}$ & Konstruksi lambung & 418 \\
$\mathbf{2}$ & Mesin \& Sis. Transmisi & 425 \\
$\mathbf{3}$ & Sangkar baling-baling & 57,5 \\
$\mathbf{4}$ & Baling-baling & 30 \\
$\mathbf{5}$ & Tempat duduk & 35 \\
$\mathbf{7}$ & Pondasi mesin & 76 \\
$\mathbf{8}$ & Sistem Kemudi & 20 \\
$\mathbf{9}$ & Jatra dan Instrumen & 25 \\
$\mathbf{1 0}$ & Baterai \& Alat Navcom & 25 \\
& Total & 1111,5
\end{tabular}

Tabel 3.

Data Berat Muatan (DWT)

\begin{tabular}{clc}
\hline No & \multicolumn{1}{c}{ Jenis Beban } & Berat $\mathbf{( K g )}$ \\
\hline $\mathbf{1}$ & 6 Personel (@ 75 Kg) & 450 \\
$\mathbf{2}$ & Logistik \& Munisi $(5 \mathrm{jam})$ & 50 \\
$\mathbf{3}$ & Persenjataan $12,7 \mathrm{~mm}$ & 20 \\
$\mathbf{4}$ & Bahan bakar $(100 \mathrm{It})$ & 80 \\
& Total & 600 \\
\hline
\end{tabular}

Untuk rancangan sistem permesinan dan penggerak di perahu rawa meliputi diesel engine, reduction gear, belt, shafting dan propeller sebagaimana ditampilkan pada Gambar 24).

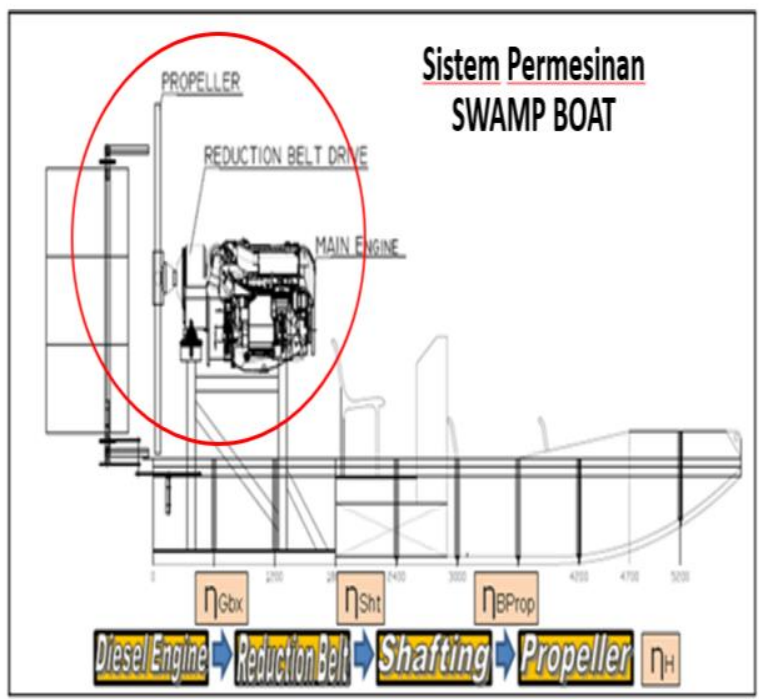

Gambar 2.

Sistem permesinan perahu rawa 
Tabel 4.

Data banding karakteristik mesin penggerak perahu rawa

\begin{tabular}{|c|c|c|c|c|c|}
\hline \multirow[t]{2}{*}{ No } & \multirow{2}{*}{$\begin{array}{l}\text { Karakteris } \\
\text { tik mesin }\end{array}$} & \multicolumn{4}{|c|}{ Jenis Mesin } \\
\hline & & $\begin{array}{c}\text { STRM } \\
\text { SE286E }\end{array}$ & $\begin{array}{c}\text { DTZ } \\
\text { BF6M1 }\end{array}$ & $\begin{array}{l}\text { CAT } \\
\text { C7B }\end{array}$ & $\begin{array}{l}\text { VOLP } \\
\text { D6-330 }\end{array}$ \\
\hline \multirow{2}{*}{1} & type & 40 & 015 & & \\
\hline & & & $\mathrm{MC}$ & & \\
\hline \multirow[t]{4}{*}{2} & Output & 205 & 214 & 205 & 237 \\
\hline & (Crank & (279) & (287) & $(275)$ & (322) \\
\hline & shaft) Kw & & & & \\
\hline & $(\mathrm{HP})$ & & & & \\
\hline \multirow[t]{3}{*}{3} & Rated & 4000 & - & 2400 & 3500 \\
\hline & speed & & & & \\
\hline & (rpm) & & & & \\
\hline \multirow[t]{4}{*}{4} & Full power & $3500-$ & - & - & - \\
\hline & speed & 4100 & & & \\
\hline & range & & & & \\
\hline & (rpm) & & & & \\
\hline \multirow[t]{2}{*}{5} & Cylinders & 6 Inline & $6 \mathrm{~V}-$ & 6 & 6 Com. \\
\hline & & & Engine & Inline & Rail \\
\hline \multirow[t]{2}{*}{6} & Displace- & $3.2 \mathrm{~L}$ & 11.91 & $7.24 \mathrm{~L}$ & $5.5 \mathrm{~L}$ \\
\hline & men $(\mathrm{T})$ & & L & & \\
\hline 7 & Bore (mm) & 85 & 132 & 110 & 103 \\
\hline \multirow[t]{2}{*}{8} & Stroke & 94 & 145 & 127 & 110 \\
\hline & $(\mathrm{mm})$ & & & & \\
\hline \multirow[t]{2}{*}{9} & Compressi & $17: 1$ & - & - & $17.51: 1$ \\
\hline & on ratio & & & & \\
\hline \multirow[t]{3}{*}{10} & Max & 570 & 285 & - & - \\
\hline & torque & & & & \\
\hline & $(\mathrm{nm})$ & & & & \\
\hline 11 & At speed & 2550 & 1500 & - & - \\
\hline & (rpm) & & & & \\
\hline \multirow[t]{3}{*}{12} & $\operatorname{Max}$ & 420 & - & - & - \\
\hline & torque & & & & \\
\hline & (lbs-ft) & & & & \\
\hline 13 & Weight & 340 & 1180 & 798 & 721 \\
\hline & $(\mathrm{kg})$ & & & & \\
\hline \multirow[t]{4}{*}{14} & Weight per & 1.22 & 4.11 & 2.90 & 2.24 \\
\hline & unit of & & & & \\
\hline & power & & & & \\
\hline & (kg/hp) & & & & \\
\hline \multirow[t]{5}{*}{15} & Dimension & $1090 x$ & $1482 x$ & 12218 & $1439 x$ \\
\hline & $(\mathrm{I} \times \mathrm{w} \times \mathrm{h})$ & $649 x$ & $1316 x$ & $x$ & $820 x$ \\
\hline & $(\mathrm{mm})$ & 754 & 1138 & 919.6 & 792 \\
\hline & & & & $x$ & \\
\hline & & & & 916.9 & \\
\hline
\end{tabular}

Catatan: STRM (Steyr Motors), DTZ (Deutz), CAT (Caterpilar), VOLP (Volvo penta). Data diolah dari berbagai sumber ${ }^{5}$.
Serta spesifikasi teknis permesinan utama (diesel engine) ditampilkan pada Tabel 4. Sebagai pembanding disini digunakan alternatif 4 data mesin diesel (marine used) dengan parameter teknis yang mendekati nilai ketentuan spesifikasi teknik perahu rawa ${ }^{5}$. Adapun parameter utama yang berpengaruh dalam seleksi mesin yang digunakan adalah ukuran mesin, besar tenaga mesin dan RPM yang cukup, berat mesin yang ringan serta memungkinkan bahan bakar biodiesel yang digunakan.

Sedangkan tipe baling-baling udara yang digunakan untuk penggerak perahu rawa digunakan tipe Whisper Tip 2 berdaun 3 terbuat dari bahan dasar material composite berpenguat carbon spar6). Baling-baling tipe ini ringan, cukup kuat dengan diameter tidak melebihi lebar perahu, banyak digunakan sebagai propulsi perahu rawa. Adapun spesifikasi teknis baling-baling perahu rawa ditampilkan pada Tabel 5.

Tabel 5.

Spesifikasi baling-baling perahu rawa

\begin{tabular}{|c|c|}
\hline Item & Dimensi \\
\hline Type & Whisper Tip 2.0 \\
\hline $\begin{array}{l}\text { Standard } \\
\text { Diameter }\end{array}$ & $78 "$ \\
\hline Diameter Range & $76 "$ to $82 "$ \\
\hline HP Range & 200 to $500 \mathrm{HP}$ \\
\hline Blade Width & $12 "$ \\
\hline Engine & Reduction drive \\
\hline Applications & engines \\
\hline Max RPM & 2700 \\
\hline Rotation & $\begin{array}{l}\text { Left or Right-Hand } \\
\text { Rotation }\end{array}$ \\
\hline Configurations & $\begin{array}{l}\text { Air propulsion } \\
3 \text { blade propeller }\end{array}$ \\
\hline
\end{tabular}

Bentuk konfigurasi baling-baling udara tipe Whisper Tip 2 berdaun 3 seperti ditampilkan pada Gambar 3.

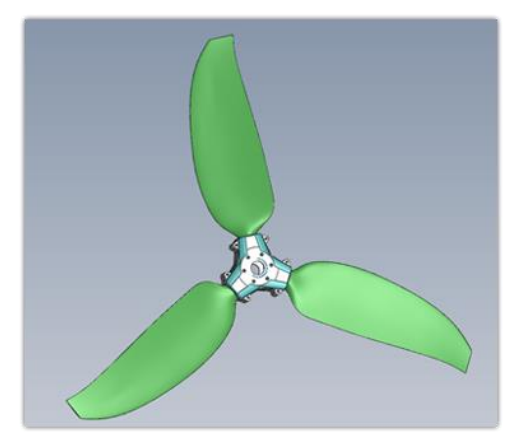

Gambar 3.

Bentuk baling-baling tipe Whisper Tip 2 
Sedangkan metodologi pengkajian yang dilakukan guna mendapatkan daya gerak perahu rawa yang optimal digunakan empat tahapan kegiatan sebagai mana disampaikan pada diagram metodologi pada Gambar 4. Pengkajian rancangan dasar perahu rawa dilakukan berawal dari data dasar spesifikasi teknis (techspec) yang disyaratkan TNI AL. Dari sini dapat dilakukan dasar optimasi bentuk rancangan awal (layout) badan/ lambung perahu rawa serta rencana lokasi penempatan sistem propulsi dan kerangka pengaman, sistem kemudi, sistem steering, logistik, persenjataan, nav-com dan tempat duduk 6 penumpang

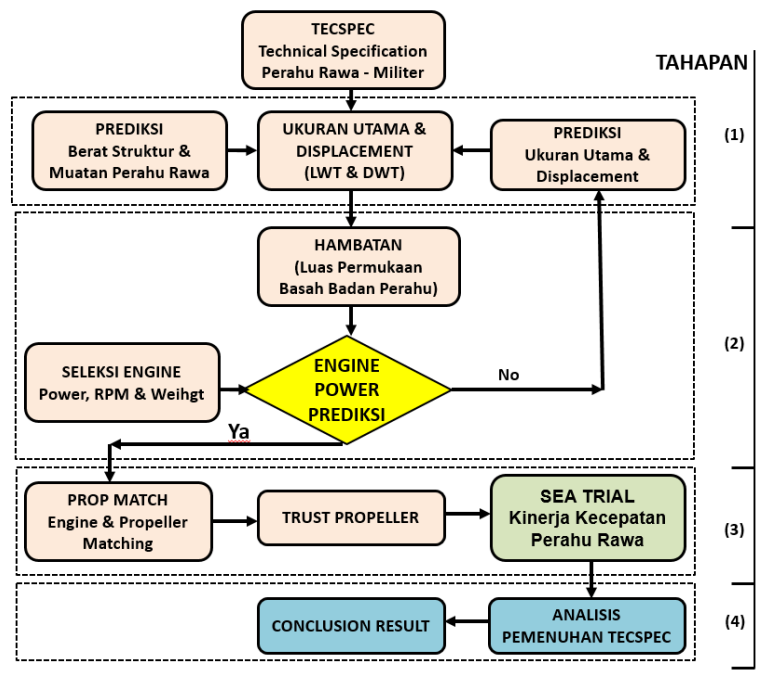

Gambar 4

Metodologi tahapan pengkajian

Dari rancangan ini sebagai Tahapan pertama dilakukan penentuan perkiraan ukuran utama serta total berat (displacement) perahu rawa. Total berat ini terdiri dari berat mati atau berat muatan (DWT) dan berat struktur (LWT). Hasil rancangan dasar perahu ini divalidasi untuk dapat memuat bobot personel dan seluruh perlengkapan operasi dan logistik. Tahapan kedua berdasarkan ukuran utama perahu, maka dilakukan perhitungan hambatan dan optimasi besar tenaga gerak perahu dengan menyesuaikan karakteristik baling-baling udara yang tersedia. Dalam optimasi perhitungan daya dorong sistem propulsi udara perahu, digunakan pendekatan perhitungan memakai basis parameter hidrodinamika dengan hambatan utama air. Sedangkan untuk hambatan udara dapat diabaikan karena dianggap bernilai kecil ${ }^{7}$. Tahapan ketiga dilakukan pengujian prototip perahu di perairan (seatrial) dan dilakukan analisa data performansi daya dorong dan kecepatan perahu. Tahap ke empat dilakukan kajian hasil pengujian (seatrial) perahu dibandingkan dengan ketentuan teknis (tecspec) yang disyaratkan TNI AL.

\section{PEMBAHASAN}

\section{A. Perancangan Berat Total Perahu}

Total bobot perahu rawa (displacement) terdiri dari komponen berat struktur dan permesinan - LWT (Light Weight) dan komponen berat muatan - DWT (Dead Weight). Komponen DWT termasuk berat seluruh personel dan perlengkapan perahu, logistik pengoperasian perahu selama 5 jam serta perlengkapan munisi senjata. Komponen utama estimasi berat LWT dan DWT ditampilkan pada Tabel 6. Estimasi total bobot perahu rawa sebesar $\pm 2000 \mathrm{Kg}$.

Tabel 6.

Estimasi total berat perahu rawa

\begin{tabular}{clc} 
No & \multicolumn{1}{c}{ Komponen Berat } & Ukuran \\
\hline $\mathbf{1}$ & LWT (Light weight) : & $\mathbf{1 2 0 0 ~ K g}$ \\
a. & Konstuksi lambung & $700 \mathrm{Kg}$ \\
b. & Sistem propulsi & $500 \mathrm{Kg}$ \\
$\mathbf{2}$ & DWT (Dead weight) : & $\mathbf{8 0 0 ~ K g}$ \\
a. & Bahan bakar 200 It & $160 \mathrm{Kg}$ \\
b. & Persenjataan 12,7 mm & $75 \mathrm{Kg}$ \\
c. & Personel 6 org (@ 75 Kg) & $450 \mathrm{Kg}$ \\
d. & Logistik & $30 \mathrm{Kg}$ \\
e. & Perlengkapan Steering, & $85 \mathrm{Kg}$ \\
& Navcom, Akomodasi & $\mathbf{2 0 0 0 ~ K g}$ \\
& Total
\end{tabular}

Distribusi persentase komponen berat badan perahu rawa (LWT) dan muatan (DWT) ditampilkan pada Gambar 5.

Prosentase Bobot Perahu Rawa (Ton)

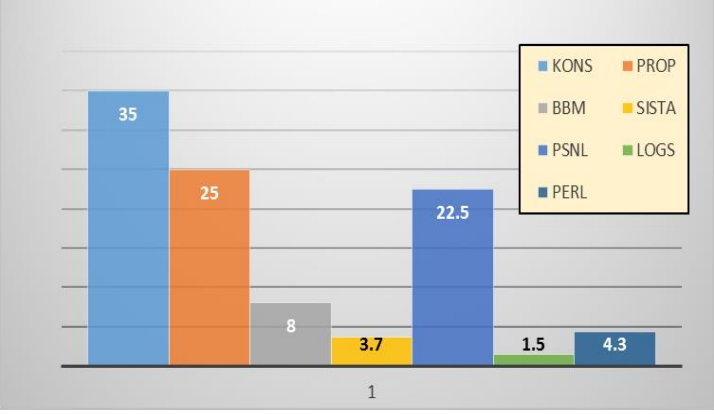

Gambar 5.

Prosentase bobot perahu rawa 


\section{B. Hambatan dan Tenaga Gerak}

Dari perhitungan estimasi total bobot perahu (displacement) meliputi berat perahu dan muatan, dapat dirancang bentuk dasar perahu menggunakan perangkat lunak Maxsurf dan dapat ditetapkan ukuran utama dan sarat air. Selanjutnya dapat diestimasi kebutuhan berat material alumunium untuk struktur dan lambung yang digunakan. Dari data ini dapat dirancang gambar rencana umum perahu rawa lengkap dengan tempat duduk, pondasi mesin, kemudi dan sangkar mesin. Adapun bentuk dasar lambung perahu rawa ditampilkan pada Gambar 6.
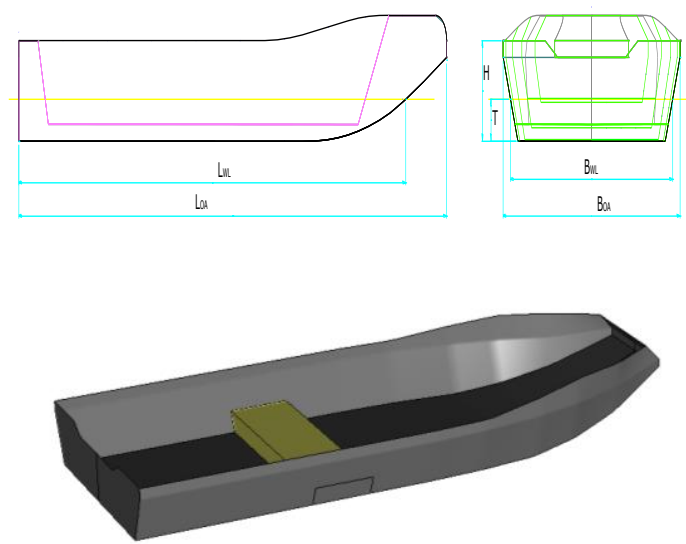

Gambar 6.

Rancangan bentuk (lines plan) perahu

Berdasarkan rancangan bentuk lambung perahu dapat dilakukan perhitungan optimasi besar hambatan dan estimasi besar tenaga penggerak perahu yang diperlukan serta pemilihan mesin penggerak dan baling-baling udara untuk perahu rawa yang sesuai pada kecepatan operasi perahu. Total hambatan perahu $\left(R_{T}\right)^{8)}$ dihitung sesuai rumus persamaan (1).

$$
R_{T}=C_{T} .0,5 \rho . S . V^{2}
$$

$$
\begin{array}{ll}
\mathrm{RT}_{\mathrm{T}} & \text { : Hambatan total perahu }\left(\mathrm{kgm} / \mathrm{s}^{2}\right) \\
\rho & : \text { Massa jenis air laut }\left(\mathrm{kg} / \mathrm{m}^{3}\right) \\
\mathrm{S} & : \text { Luas basah lambung perahu }\left(\mathrm{m}^{2}\right) \\
\mathrm{V} & : \text { Kecepatan operasi perahu }\left(\mathrm{m} / \mathrm{s}^{2}\right) \\
\mathrm{C}_{\mathrm{T}} & : \text { Koefisien total hambatan }
\end{array}
$$

Optimasi hambatan perahu dihitung dengan cara memvariasikan kedalaman sarat perahu rawa dan dipilih Coefficient block (Cb) lambung perahu yang paling optimum. Hal ini dimaksudkan untuk dapat mengakomodasi bobot total perahu (displacement) sehingga mampu memuat nilai LWT dan DWT perahu.
Sedangkan untuk perhitungan luas permukaan basah lambung perahu digunakan data luas basah lambung pada 10 garis air dimulai dari sarat air awal 0,05 m sampai dengan sarat $0,5 \mathrm{~m}$ dengan penambahan selisih kedalaman sebesar 0,05 m. Grafik hubungan nilai hambatan $(R)$, luas permukaan basah lambung (S), Displacement (Displ) dan Coefficient block (Cb) perahu rawa ditampilkan pada Gambar 7.

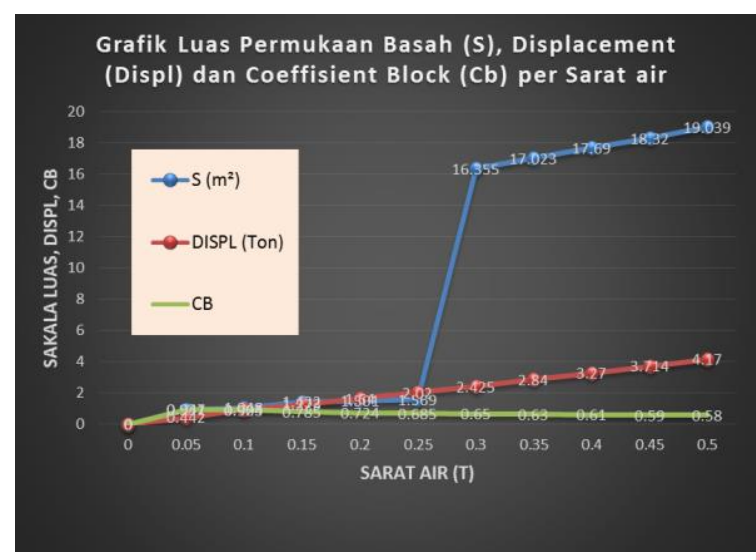

Gambar 7.

Grafik Hambatan fungsi luas permukaan dan Variasi sarat air dan Coefficient block

Dari pembacaan data grafik pada Gambar 7 didapatkan pada sarat air di tengah (midship) maksimum 0,5 m, nilai luas permukaan basah lambung perahu 19,039 $\mathrm{m}^{2}$, Displacement perahu 4,171 ton dan $\mathrm{Cb}$ lambung perahu 0,585. Sehingga nilai total optimasi hambatan perahu $3405,801 \mathrm{Kgm} / \mathrm{s}^{2}$ (Newton).

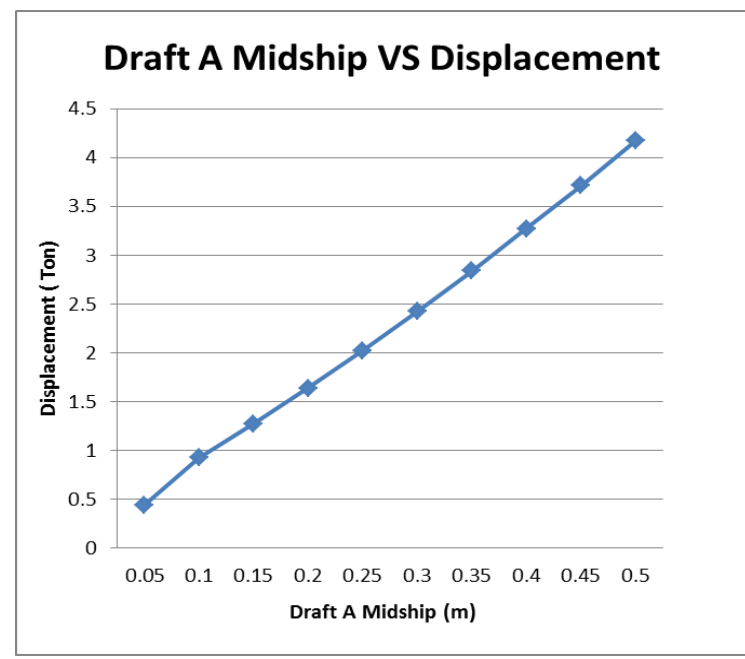

Gambar 8.

Hubungan Draft a Midship dan Displacement (perhitungan Hidrostatika) 
Dari data nilai hambatan perahu yang didapatkan, selanjutnya dapat ditentukan besar tenaga efektif penggerak yang dibutuhkan untuk mendorong perahu melaju $\left(P_{e}\right)$. Perhitungan numerik secara empiris kebutuhan daya penggerak mengacu pada persamaan $(2)^{9)}$. Pada perhitungan ini nilai efisiensi optimum (losses), yaitu pertimbangan hilangnya tenaga penggerak akibat transmisi tenaga gerak perahu belum dimasukan.

$$
P_{e}=R_{T} . V
$$

Disini RT $\left(\mathrm{kgm} / \mathrm{s}^{2}\right)$ merupakan nilai hambatan total perahu rawa di air dan $\mathrm{V}$ $\left(\mathrm{m} / \mathrm{s}^{2}\right)$ merupakan kecepatan dinas/ operasi perahu. Dengan mengacu tecspec perahu rawa, untuk kecepatan perahu 20 knot, nilai $\mathrm{Pe}$ dari persamaan (2) diperoleh sebesar 35011,639 Watt atau setara 47,78 HP. Menurut metode pendekatan Savitsky 10) untuk kapal cepat pada kondisi planing hulls nilai $\mathrm{Pe}$ mempunyai efisiensi $\pm 80 \%$ karena hambatan air badan kapal berkurang, sehingga diperoleh nilai $\mathrm{Pe}$ sebesar 38,18 HP. Nilai ini tidak terpaut jauh jika dibandingkan dengan hasil perhitungan secara numerik berbasis perhitungan propulsi di air menggunakan perangkat lunak Maxsurf. Pada rancangan kecepatan 20 knot, nilai $\mathrm{Pe}$ mencapai 38,93 HP dan pada rancangan kecepatan perahu 50 knot nilai $\mathrm{Pe}$ mencapai 267,3 HP seperti hasil perhitungan yang ditampilkan pada Tabel 7. Untuk mendapatkan besar tenaga penggerak total yang diperlukan dengan pendekatan perhitungan propulsi di air nilai $\mathrm{Pe}$ harus dikalikan dengan total efisiensi mekanis transmisi $(\mathrm{nH})$ sehingga akan didapatkan nilai optimum daya mesin perahu. Namun dalam kajian di sini pada perahu rawa akan digunakan sistem propulsi baling-baling udara dengan pendekatan perhitungan di udara. Untuk itu perlu dihitung gaya dorong (thrust) sistem propulsi udara yang akan digunakan, mendorong perahu rawa melaju dengan kecepatan 20 knot

Tabel 7.

Hasil Perhitungan Numerik Hambatan dan Tenaga gerak

\section{Kecepatan Hambatan Efisiensi $\mathbf{8 0 \%}$ (Savitsky)}

$\begin{array}{rrr}\text { Knot } & \text { Newton } & \text { Power (HP) } \\ 0 & -- & - \\ \mathbf{1 , 2 5} & -- & - \\ \mathbf{2 , 5} & -- & --\end{array}$

$\begin{array}{rrr}\mathbf{3 , 7 5} & -- & -- \\ \mathbf{5} & -- & -- \\ \mathbf{6 , 2 5} & -- & -- \\ \mathbf{7 , 5} & -- & - \\ \mathbf{8 , 7 5} & -- & - \\ \mathbf{1 0} & 2009,55 & 17,33 \\ \mathbf{1 1 , 2 5} & 2136,64 & 20,73 \\ \mathbf{1 2 , 5} & 2206,8 & 23,79 \\ \mathbf{1 3 , 7 5} & 2232,24 & 26,47 \\ \mathbf{1 5} & 2233,53 & 28,89 \\ \mathbf{1 6 , 2 5} & 2227,87 & 31,22 \\ \mathbf{1 7 , 5} & 2226,35 & 33,6 \\ \mathbf{1 8 , 7 5} & 2235,17 & 36,14 \\ \mathbf{2 0} & 2257,34 & 38,93 \\ \mathbf{2 1 , 2 5} & 2294,07 & 42,04 \\ \mathbf{2 2 , 5} & 2345,52 & 45,51 \\ \mathbf{2 3 , 7 5} & 2411,37 & 49,39 \\ \mathbf{2 5} & 2491,01 & 53,7 \\ \mathbf{2 6 , 2 5} & 2583,79 & 58,49 \\ \mathbf{2 7 , 5} & 2689 & 63,77 \\ \mathbf{2 8 , 7 5} & 2806 & 69,57 \\ \mathbf{3 0} & 2934,17 & 75,91 \\ \mathbf{3 1 , 2 5} & 3072,98 & 82,81 \\ \mathbf{3 2 , 5} & 3221,93 & 90,3 \\ \mathbf{3 3 , 7 5} & 3380,59 & 98,39 \\ \mathbf{3 5} & 3548,57 & 107,1 \\ \mathbf{3 6 , 2 5} & 3725,53 & 116,46 \\ \mathbf{3 7 , 5} & 3911,16 & 126,48 \\ \mathbf{3 8 , 7 5} & 4105,21 & 137,18 \\ \mathbf{4 0} & 4307,43 & 148,58 \\ \mathbf{4 1 , 2 5} & 4517,62 & 160,7 \\ \mathbf{4 2 , 5} & 4735,58 & 173,56 \\ \mathbf{4 3 , 7 5} & 4961,14 & 187,17 \\ \mathbf{4 5} & 5194,17 & 201,56 \\ \mathbf{4 6 , 2 5} & 5434,52 & 216,75 \\ \mathbf{4 7 , 5} & 5682,06 & 232,75 \\ \mathbf{4 8 , 7 5} & 5936,71 & 249,58 \\ \mathbf{5 0} & 6198,34 & 267,26 \\ & & \end{array}$

Tabel 8.

Hambatan dan Engine - Propeller Thrust

\begin{tabular}{cccc}
\hline Speed & $\begin{array}{c}\text { Putaran } \\
\text { Prop. }\end{array}$ & Hambatan & $\begin{array}{c}\text { Eng Prop } \\
\text { Thrust } \\
\mathbf{8 0} \% \text { Eff }\end{array}$ \\
\hline Knot & RPM & Newton & Newton \\
\hline $\mathbf{0}$ & 0 & 0 & 0 \\
$\mathbf{1 , 2 5}$ & 600 & 0 & 0
\end{tabular}




\begin{tabular}{|c|c|c|c|}
\hline 2,5 & 650 & 0 & 0 \\
\hline 3,75 & 700 & 0 & 0 \\
\hline 5 & 750 & 0 & 0 \\
\hline 6,25 & 800 & 0 & 0 \\
\hline 7,5 & 850 & 0 & 0 \\
\hline 8,75 & 900 & 0 & 0 \\
\hline 10 & 950 & 2009,55 & 44609,60 \\
\hline 11,25 & 1000 & 2136,64 & 39652,98 \\
\hline 12,5 & 1500 & 2206,8 & 35687,68 \\
\hline 13,75 & 2000 & 2232,24 & 32443,34 \\
\hline 15 & 2150 & 2233,53 & 29739,73 \\
\hline 16,25 & 2200 & 2227,87 & 27452,06 \\
\hline 17,5 & 2250 & 2226,35 & 25491,20 \\
\hline 18,75 & 2300 & 2235,17 & 23791,79 \\
\hline 20 & 2350 & 2257,34 & 22304,80 \\
\hline 21,25 & 2400 & 2294,07 & 20992,75 \\
\hline 22,5 & 2450 & 2345,52 & 19826,49 \\
\hline 23,75 & 2500 & 2411,37 & 18782,99 \\
\hline 25 & 2550 & 2491,01 & 17843,84 \\
\hline 26,25 & 2600 & 2583,79 & 16994,13 \\
\hline 27,5 & 2650 & 2689,00 & 16221,67 \\
\hline 28,75 & 2700 & 2806,00 & 15516,38 \\
\hline 30 & 2700 & 2934,17 & 14869,87 \\
\hline 31,25 & 2700 & 3072,98 & 14275,07 \\
\hline 32,5 & 2700 & 3221,93 & 13726,03 \\
\hline 33,75 & 2700 & 3380,59 & 13217,66 \\
\hline 35 & 2700 & 3548,57 & 12745,60 \\
\hline 36,25 & 2700 & 3725,53 & 12306,10 \\
\hline 37,5 & 2700 & 3911,16 & 11895,89 \\
\hline 38,75 & 2700 & 4105,21 & 11512,15 \\
\hline 40 & 2700 & 4307,43 & 11152,40 \\
\hline 41,25 & 2700 & 4517,62 & 10814,45 \\
\hline 42,5 & 2700 & 4735,58 & 10496,38 \\
\hline 43,75 & 2700 & 4961,14 & 10196,48 \\
\hline 45 & 2700 & 5194,17 & 9913,24 \\
\hline 46,25 & 2700 & 5434,52 & 9645,32 \\
\hline 47,5 & 2700 & 5682,06 & 9391,49 \\
\hline 48,75 & 2700 & 5936,71 & 9150,69 \\
\hline 50 & 2700 & 6198,34 & 8921,92 \\
\hline
\end{tabular}

Dengan diambil nilai gaya hambatan perahu rawa berbasis perhitungan propulsi di air (Savitsky method), maka nilai gaya dorong (thrust) baling-baling udara perahu rawa berbasis perhitungan sistem propulsi udara harus setara dengan nilai hambatan. Untuk itu dalam iterasi perhitungan ini digunakan jenis propeller dengan spesifikasi teknik sebagaimana pada Tabel 5. Adapun hasil perhitungan Propeller and Engine thrust ini ditampilkan pada Tabel 8.

\section{Pemilihan Propeller Udara}

Pemilihan baling-baling Whisper Tip ${ }^{5)}$ sebagai tipe baling-baling udara yang digunakan pada perahu rawa didasarkan pada spesifikasi teknis baling-baling yang ditampilkan pada Tabel 5. Bentuk bilah baling-baling memiliki profil sangat tajam dengan tip penyapu yang agresif serta mempunyai kinerja unggul. Desain ini akan mengurangi gaya hambatan (drag) dan kebisingan akibat putaran baling-baling, sehingga baling-baling dapat menghasilkan gaya dorong (propeller thrust) yang optimum, sehingga akan dapat menghemat kebutuhan bahan bakar. Baling-baling yang digunakan adalah baling-baling udara dirancang sebagai sistem propulsi untuk perahu rawa (air boat/ swamp boat) dan dipasang di atas permukaan air. Sistem propulsi ini mampu memberikan gaya dorong (thrust) untuk menggerakkan badan perahu maju dengan kecepatan operasi rata-rata $\geq 20$ knot. Untuk perhitungan gaya dorong baling-baling $T_{p}$ (propeller thrust) digunakan rumusan pada persamaan (3) dan (4) dan tenaga pendorong pada poros penggerak $P_{s}$ (shaft power) digunakan rumusan pada persamaan (5) dan (6) ${ }^{11)}$.

$$
\begin{aligned}
& T_{p}=C_{T} \cdot \boldsymbol{\rho} \cdot n^{2} \cdot D^{4} \\
& C_{T}=(J=V / n D, p / D, \text { tipe prop })
\end{aligned}
$$

$\mathrm{C}_{\mathrm{T}} \quad$ : koefisien pendorong

p : : Densitas udara $\left(\mathrm{kg} / \mathrm{m}^{3}\right)$

$\mathrm{n} \quad$ : putaran baling-baling $(\mathrm{rpm})$

D : diameter baling-baling $(\mathrm{m})$

$\mathrm{V} \quad$ : kecepatan maju baling-baling $(\mathrm{m} / \mathrm{s})$

$\mathrm{p} \quad$ : pitch baling-baling $(\mathrm{m})$

$$
\begin{aligned}
& P_{s}=C_{p} \cdot \rho \cdot n^{3} \cdot D^{5} / 550 \\
& C_{p}=(J=V / n D, p / D)
\end{aligned}
$$

$\mathrm{C}_{\mathrm{p}} \quad$ : koefisien tenaga

Disini besaran nilai trust propeller merupakan fungsi dari nilai pitch, bentuk dan diameter bilah baling-baling, putaran balingbaling, densitas udara dan koefisien pendorong (thrust Coefficient) serta pitch kecepatan maju (forward velocity). Sedangkan nilai perhitungan besar tenaga pendorong pada poros penggerak merupakan fungsi dari jumlah putaran, diameter bilah baling-baling, densitas udara, koefisien tenaga (power coefficient), pitch - 
kecepatan maju (forward velocity) pada efisiensi baling-baling $80 \%{ }^{111}$. Untuk nilai daya mesin penggerak didapatkan dari nilai tenaga dorong poros penggerak $\left(P_{s}\right)$ dikalikan nilai total efisiensi mekanik transmisi daya $(\eta \mathrm{H})$. Pada simulasi perhitungan gaya dorong baling-baling $T_{p}$ (propeller thrust) dan tenaga penggerak perahu rawa berbasis sistem propulsi memakai baling-baling udara, disini digunakan data perhitungan numerik hingga rancangan kecepatan maksimum 50 knot. Hal ini dimaksudkan dengan mempertimbangkan adanya penurunan losses tenaga pada baling-baling seiring dengan meningkatnya kecepatan perahu rawa. Terlihat bahwa untuk mencapai rancangan kecepatan perahu 20 knot, nilai RPM baling-baling masih mencapai 2350 atau sekitar $80 \%$ dari maksimum RPM sesuai spesifikasi baling-baling. Oleh karenanya untuk mendapatkan nilai optimum daya gerak perahu rawa, maka rancangan kecepatan perahu rawa masih optimis dapat dicapai hingga 50 knot pada maksimum RPM balingbaling.

Dengan didapatkan nilai optimum kebutuhan daya mesin penggerak, berikutnya dapat ditentukan besar dan jenis mesin penggerak sesuai kebutuhan pemakaian di perahu.

\section{Penetapan Daya Penggerak}

Berdasarkan acuan hasil perhitungan hambatan (resistance) dan kebutuhan optimum tenaga gerak pendorong perahu rawa untuk dapat mencapai kecepatan operasi $\geq 20$ knot, maka dilakukan seleksi teknis data mesin yang tersedia. Dari dasar kajian data ke-4 alternatif mesin perahu rawa seperti tercantum pada Tabel 4, terlihat bahwa kemampuan teknis mesin diesel Steyr Motors Type SE286E40 memiliki kelebihan penilaian dibandingkan dengan ke 3 (tiga) mesin lainnya ${ }^{4)}$. Dengan besar tenaga mesin yang relatif hampir sama, namun ditinjau dari kecilnya rasio berat per unit tenaga mesin, menunjukan mesin Steyr Motor jauh lebih ringan dari pada 3 mesin lainnya seperti yang ditunjukkan pada Tabel 4. Penilaian ini sangat penting terkait efektifitas daya gerak serta pengaturan titik berat perahu karena peletakan mesin yang ditempatkan diatas badan perahu. Hal ini sangat berpengaruh pada kondisi stabilitas statis perahu rawa. Disamping itu dengan tenaga mesin yang sama mesin Steyr Motor memiliki ukuran lebih kecil. Mesin dapat menggunakan bahan bakar biodiesel yang tidak terlalu sulit didapatkan di daerah pedalaman. Pada
Gambar 7 ditampilkan bentuk Mesin Styer yang digunakan pada perahu rawa dengan ukuran utama (I x w x h) : $1090 \times 649 \times 754$ $(\mathrm{mm})$.

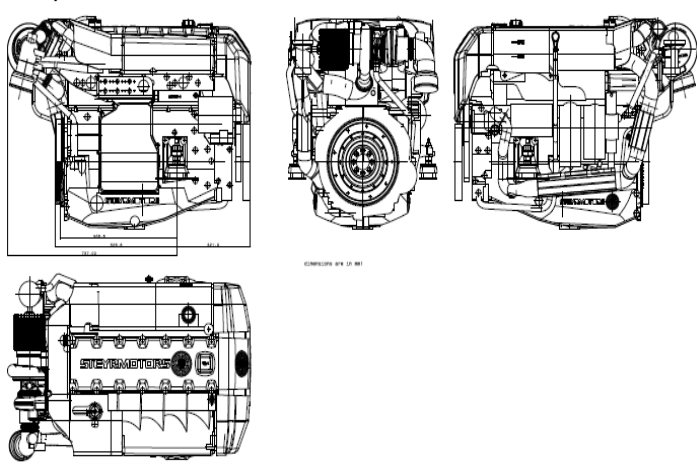

Gambar 9.

Mesin Steyr Motors Tipe SE286E40

Dengan data daya dorong yang sepadan baik melalui perhitugan berbasis propulsi di air maupun berbasis propulsi udara pada perahu rawa dengan hambatan 6198,34 N $\left(\mathrm{kgm} / \mathrm{s}^{2}\right)$ dan rancangan kecepatan optimal maksimum 50 knot, maka selanjutnya dapat dirancang daya dorong perahu rawa untuk ke dua jenis sistem propulsi. Pada penggunan sistem propulsi air dibutuhkan mesin penggerak sebesar 267,3 HP. Untuk menggunaan sistem propulsi udara dengan basis perhitungan gaya dorong baling-baling udara berefisiensi $80 \%{ }^{11)}$, dibutuhkan tenaga gerak pendorong $\mathrm{P}_{\mathrm{s}}=8921,92 \mathrm{~N}$, setara dengan kebutuhan daya mesin penggerak sebesar 238 HP. Pada perhitungan di sini digunakan nilai efisiensi maksimal mechanical power transmission losses (50\%) pada sistem propulsi perahu rawa yang terdiri dari komponen sistem transmisi vertical belt transmission, reduction gear dan bearing ${ }^{5,6)}$. Untuk selanjutnya dapat ditetapkan jenis mesin diesel penggerak perahu dengan kebutuhan daya berkisar $\pm 238-268$ HP. Dipilih mesin diesel yang tersedia dengan daya 279 HP. Dari hasil perhitungan numerik berbasis sistem propulsi udara dapat digambarkan grafik perbandingan nilai hambatan dan gaya dorong mesin ke balingbaling (engine propeller thrust) dengan nilai efisiensi baling-baling $80 \%$, sebagaimana pada Gambar 10.

Dari grafik hubungan antara nilai capaian kecepatan, hambatan yang terjadi serta engine-propeler thrust pada perahu rawa dalam perhitungan numerik menunjukan bahwa pada kecepatan sekitar 10 knot, perahu mulai bergerak, rasio nilai hambatan mulai naik mencapai $2000 \mathrm{~N}$ dan engine propeller thrust sudah mencapai $44000 \mathrm{~N}$ atau $4,5 \%$. Namun rasio ini menurun seiring 
dengan peningkatan kecepatan perahu. Hal ini terkait degan pengaruh grafik karakteristik lossess parameter gaya dorong (propeller thrust) baling-baling ${ }^{12)}$.

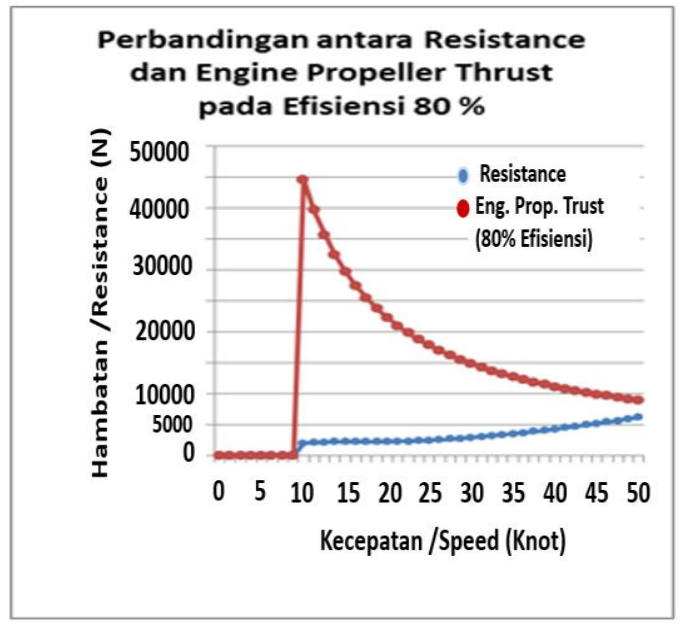

Gambar 10

Hubungan hambatan (Resistance) dan gaya dorong 80\% (Engine - Propeller Thrust) pada kapal rawa

Dengan didapatkan nilai optimum daya gerak perahu rawa secara numerik, maka untuk pembuktian konsep desain (proof of design concept) dilakukan pembangunan dan pengujian pelayaran prototip perahu rawa di lapangan. Dalam kegiatan pengujian ini digunakan prototip perahu rawa hasil implementasi kegiatan kerjasama TNI-AL, BPPT dan galangan BUMS-MPE ${ }^{12}$. Pelaksanaan validasi hasil optimasi daya gerak perahu rawa, dilakukan melalui serangkaian pengujian berlayar (seatrial) di perairan terbatas sesuai ketentuan osreqspectec TNI AL.

\section{E. Pengujian pelayaran Perahu Rawa}

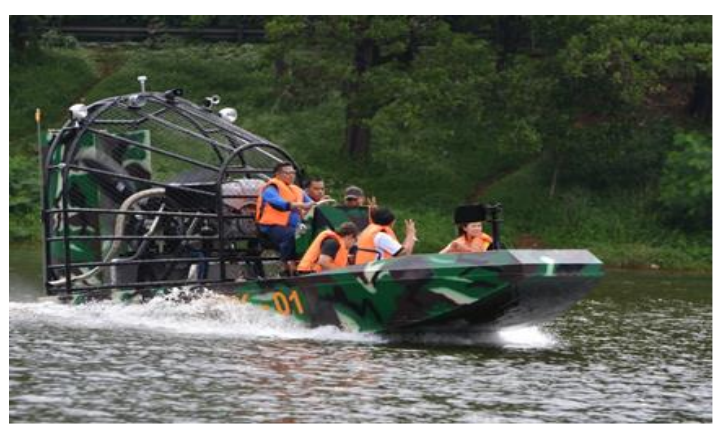

Gambar 11.

Pengujian perahu rawa

Pengujian perahu rawa dilaksanakan dengan kondisi beban muatan (payload) disesuaikan dengan ketentuan untuk operasi militer dengan pengawakan 6 orang ( 1 awak juru mudi, 1 orang penembak dan 4 orang prajurit patroli) $)^{13)}$. Gambar 11 menampilkan pengujian berlayar perahu rawa dan hasil pengujian ditampilkan pada Tabel 9.

Tabel 9.

Hasil Pengujian Berlayar

\begin{tabular}{|c|c|c|c|c|}
\hline Durasi & $\begin{array}{l}\text { Eng. } \\
\text { Rpm }\end{array}$ & $\begin{array}{l}\text { Prop. } \\
\text { RPM }\end{array}$ & $\begin{array}{l}\text { Action } \\
\text { \%MCR }\end{array}$ & $\begin{array}{l}\text { Speed } \\
\text { (knot) }\end{array}$ \\
\hline $\begin{array}{l}5 \mathrm{~min} \\
6 \mathrm{sec}\end{array}$ & 1200 & 810 & $25 \%$ & 4,3 \\
\hline $\begin{array}{c}4 \mathrm{~min} \\
44 \mathrm{sec}\end{array}$ & 1200 & 810 & $25 \%$ & 4,4 \\
\hline $\begin{array}{c}3 \mathrm{~min} \\
35 \mathrm{sec}\end{array}$ & 1900 & 1282,5 & $25 \%$ & 5,8 \\
\hline $\begin{array}{l}4 \mathrm{~min} \\
8 \mathrm{sec}\end{array}$ & 1900 & 1282,5 & $50 \%$ & 5,4 \\
\hline $\begin{array}{l}2 \mathrm{~min} \\
42 \mathrm{sec}\end{array}$ & 2800 & 1890 & $50 \%$ & 8,1 \\
\hline $\begin{array}{c}2 \mathrm{~min} \\
58 \mathrm{sec}\end{array}$ & 2800 & 1890 & $50 \%$ & 7,4 \\
\hline $\begin{array}{c}1 \mathrm{~min} \\
46 \mathrm{sec}\end{array}$ & 3000 & 2025 & $66 \%$ & 14,6 \\
\hline $\begin{array}{c}2 \mathrm{~min} \\
34 \mathrm{sec}\end{array}$ & 3000 & 2025 & $66 \%$ & 13 \\
\hline $\begin{array}{l}1 \mathrm{~min} \\
4 \mathrm{sec}\end{array}$ & 3200 & 2160 & $75 \%$ & 25 \\
\hline $\begin{array}{c}1 \mathrm{~min} \\
47 \mathrm{sec}\end{array}$ & 3200 & 2160 & $75 \%$ & 25 \\
\hline $50 \mathrm{sec}$ & 3500 & 2362,5 & $100 \%$ & 27 \\
\hline $58 \mathrm{sec}$ & 3500 & 2362,5 & $100 \%$ & 30 \\
\hline
\end{tabular}

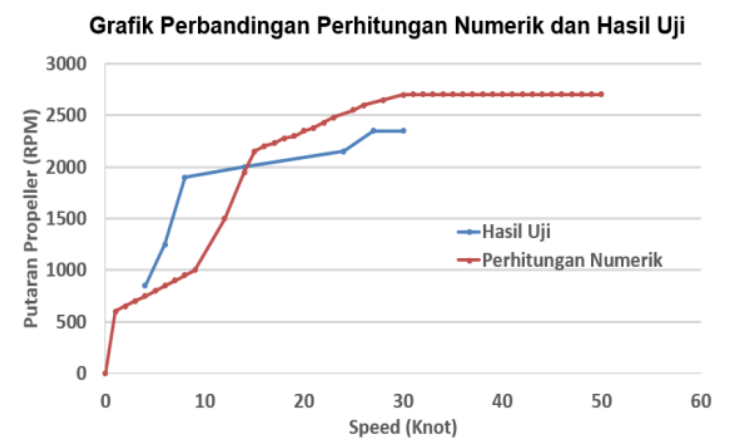

Gambar 12.

Perbandingan data pengujian numerik dan seatrial untuk putaran baling-baling (RPM) dan kecepatan perahu (knot)

Pada Gambar 12 ditampilkan grafik perbandingan antara putaran baling-baling dan kecepatan perahu rawa berdasarkan data dari perhitungan numerik daya gerak dan data hasil pengukuran pada perahu saat di lapangan. Dari data ini terlihat grafik peningkatan putaran baling-baling perahu seiring dengan peningkatan kecepatan 
perahu yang menunjukan rata-rata arah yang proposional. Pengujian kecepatan perahu di lapangan disudahi sampai kecepatan 30 knot, mengingat faktor keselamatan operasional perahu dengan kondisi lintasan perahu di area perairan yang terbatas. Dengan hasil uji pelayaran ini terlihat capaian kinerja kecepatan perahu rawa telah melebihi persyaratan kecepatan opsrec yang ditetapkan 20 knot

\section{SIMPULAN}

Optimasi rancangan Perahu Rawa untuk pemenuhan ketentuan opsreq militer menghasilkan ukuran utama Panjang $x$ Lebar $x$ Sarat $(5,8 \times 2,1 \times 0,25) \mathrm{m}$ dengan bobot maksimum (displacement) sebesar $2000 \mathrm{Kg}$. Hasil simulasi perhitungan numerik berbasis kondisi propulsi di air, pada kecepatan 20 knot, besar gaya hambatan perahu rawa mencapai 2257,34 N dan pada kecepatan 50 knot, gaya hambatan perahu mencapai $6198,34 \mathrm{~N}$ dengan kebutuhan daya dorong perahu sebesar 38,9 HP dan 267,3 HP. Hasil simulasi perhitungan numerik berbasis kondisi propulsi udara dengan nilai hambatan air perahu 2257,34 N, kecepatan 20 knot dan nilai hambatan $6198,34 \mathrm{~N}$, pada rancangan kecepatan 50 knot membutuhkan besar gaya dorong baling-baling (Engine propeller thrust) pada efisiensi $80 \%$ sebesar 22304,80 $\mathrm{N}$ dan 8921,92 N. Berdasarkan hasil perhitungan simulasi untuk kebutuhan minimum daya gerak pendorong perahu rawa pada kecepatan sampai 50 knot perlu sebesar \pm 238 - 268 HP dan dari hasil kajian teknis spesifikasi mesin, maka digunakan alternatif sistem propulsi penggerak perahu berupa mesin diesel Steyr Motors Type SE286E40 dengan daya $275 \mathrm{HP}$ dan baling-baling udara Whirlwind type Whisper Tip 2.0, diameter 78". Hasil pencapaian kinerja kecepatan operasi perahu rawa berdasarkan perhitungan simulasi numerik menggunakan optimasi pemakaian data teknis mesin dan balingballing yang dipilih, didapatkan rancangan kecepatan perahu rawa mampu mencapai 50 knot. Dibandingkan dengan kecepatan operasi 20 knot yang ditetapkan pada opsreqspectec, presentase peningkatan rancangan kecepatan perahu rawa mencapai $150 \%$. Berdasarkan hasil pengujian perahu rawa di lapangan didapatkan data pengukuran putaran baling-baling perahu mencapai 2362,5 RPM pada capaian kecepatan sampai 30 knot. Dari hasil uji ini kinerja kecepatan perahu sudah mampu mencapai peningkatan $50 \%$ dari kecepatan yang dipersyaratkan 20 knot pada opsrec-spectec TNI AL.

\section{UCAPAN TERIMA KASIH}

"Perancangan Daya Gerak Perahu Rawa berbasis propulsi udara guna meningkatkan kinerja wahana patroli TNI AL", merupakan hasil kajian teknis, bagian dari program kegiatan Kerjasama teknis, Rancang Bangun Prototip Swamp Boat didukung oleh Dislitbang TNI AL, PTIPK BPPT dan PT Mega Perkasa Engineering tahun 2013. Ucapan terima kasih disampaikan kepada Dr. Ir. Erzi A. Gani, ME, mantan Deputi Ka. BPPT Bid. TIRBR, yang telah mendukung sepenuhnya pelaksanaan kegiatan kerjasama ini.

\section{DAFTAR PUSTAKA}

1. Subagja, D., Kuasai medan untuk menangkan pertempuran di laut, Buletin Hidro-Oseanografi, Dishidros TNI AL, Ed. 02/XIII, 2012.

2. Dislitbang TNI AL, Technical Specification (Tecspec) Rancang Bangun Perahu Rawa (Swamp Boat), $2013 \quad$ (Tidak dipublikasikan)

3. Lepek, A.P., Optimization of an Air boat Design, The Lee Honors Collage, Thesis, Western Michigan University, USA, 2012.

4. Dumment R., Design of Propulsion Systems for High-speed Craft The Use of Airboat in lce and Water Rescue Emergencies. Fire Eng., pp. 113-126, 2004.

5. Data berbagai sumber : Commercial Marine Engine brochures / web-side.

6. Whirlwind Propellers, Composite Airboat Propeller Instruction, https://whirlwindpropellers.com/airboats/w p-

content/uploads/2015/05/WhirlWind_Com posite_Airboat_Propeller_Instructions_112 013.pdf, diakses April $20 \overline{1} 8$.

7. Insel, M. and Molland, A.F., An Investigation into the Resistance Components of High Speed Displacement Catamarans. Meeting of the Royal Institution of Naval Architect, UK, 1991.

8. Sv. Aa. Harvald, Tahanan dan Propulsi Kapal (buku terjemahan), Airlangga University Press, Surabaya, 1991.

9. Basic Principle of Ship Propulsion, https://spain.mandieselturbo.com/docs/libr ariesprovider10/sistemas-propulsivosmarinos/basic-principles-of-shippropulsion.pdf?sfvrsn=2, diakses April 2018.

10.Savitsky, D., Hydrodynamic design of planning hulls, Marine Technology Journal, Vol 1, No. 1, p. 71-95, SNAMEUSA, Oct 1964. 
11.Garner, W.B., Model Airplane Propeller, Air-Propeller research document, wbgarner08@verizon.net, March 2009.

12.Pusat Teknologi Industri Pertahanan dan Keamanan-BPPT, Laporan Rancang bangun kapal swampboat, 2013 (Tidak dipublikasikan).
13.Paripurna, A., Samudro, Suwahyu, Noor F.R, Pengujian Berlayar Prototip Kapal Patroli Rawa - TNI AL Untuk Pemenuhan Standar Operasi Militer, Proceding Seminar 12th AMTeQ-LIPI, GWB Puspiptek, Serpong, Tangsel, 12 Oktober 2017. 